\title{
128 液柱内を上昇する気泡列の挙動計測
}

\author{
関西大院 山内 慎, 関西大学 植村 知正

\section{Motion Measurement of Rising Bubble Trains in Cylindrical Pipe} \\ Makoto YAMAUCHI, Tomomasa UEMURA \\ Kànsai Univ., 3-3-35, Yamate, Suita, Osaka 564-8680, Japan
}

\begin{abstract}
In this paper, authors have applied PTV and PIV techniques to measure behaviors of rising bubble and induced flow in a vertical cylindrical pipe.

The bubbles rise in regular space from a bottom nozzle of the pipe filled with silicone oil. In the experimental conditions, Reynolds number is from 0.8 to 1.0 at the diameter ratio 0.25 of the bubble to the pipe. Bubbles are pictured from front and side directions by two CCD cameras. By analyzing individual pictures, shapes and dimensions are obtained. From the analysis of sequential pictures, velocities of the bubbles and the flow are measured. The data enable to estimate apparent drag coefficients of the rising bubbles.
\end{abstract}

\section{1. はじめに}

垂直管内を上昇する気泡は複雑な形状変化 を伴ってゆらぎながら上昇する。また，単一ノ ズルから出て上昇する気泡列の場合, 後から上 昇する気泡は，前の気泡の後流によって上昇速 度が速くなり，やがて前の気泡に追いつき衝突 する現象が見られる。気泡の形状変化や心らぎ は気泡の大きさ，液体の粘度，界面のつりあい や周りの流動などが深く関係している。このよ うな上昇気泡の挙動を定量的に明らかにするた めには，時々刻々の計測が不可欠である.

そこで本研究では，単一ノズルから出た気泡 列の上昇挙動を明らかにするために画像計測を 用いた。画像計測は，気泡流動や気泡の上昇に 伴う相対流動を同時に計測することができる。 実験では，気泡の上昇速度に PTV，気泡の上昇 に伴う管内の非定常流れの速度分布の計測に PIVを用いた。 また，気泡の上昇経路や表面積 を計測し，上昇する気泡の抵抗係数を求め，基 礎的なデータを得ている。

\section{2. 実験装置と解析方法}

\section{1. 実駼装置及び方法}

撮影に用いた実験装置の概略を fig.1に示す. ガラス製の薄肉円管 $(\phi 32.4 \times 700, \mathrm{t}=0.7)$ 内に はシリコンオイルを入れ，下方に設けたノズル （申5）より空気を吹き込んでいる.

気泡は, 正面, 側面方向から 2 台の CCD ビデ
オカメラを用いて撮影した。また，気泡やそれ に伴う流動状態のみを撮影する目的で，赤外線 カメラを設置した。この場合，シート状の光源 にするため赤外線レーザ $(40 \mathrm{~mW})$ を用いた。 トレーサは白い微粒子（直径 $0.1 \mathrm{~mm}$ 以下）を 用い, シリコン油内で十分中立浮動を保つもの であった。

撮影した画像はフレームグラバを介してパ ソコンに取り込み，1/60s 間隔のデジタル画像 として記録・保存している。

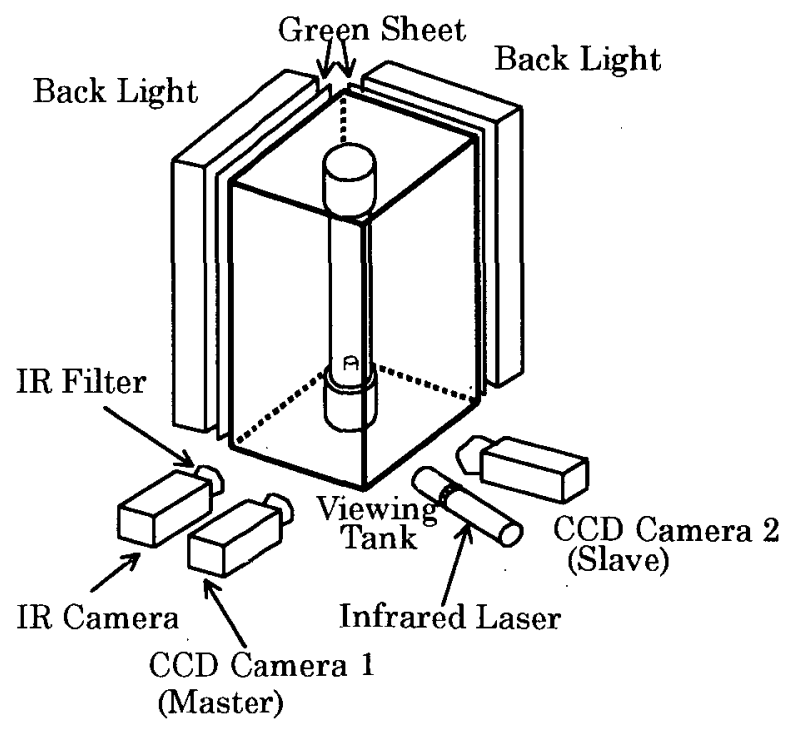

Fig.1 Schematic view of experimental set up 


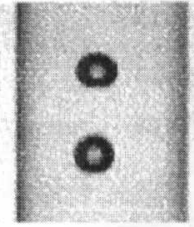

(a)

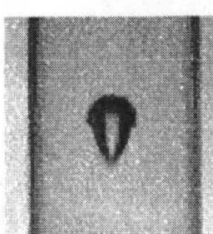

(c)

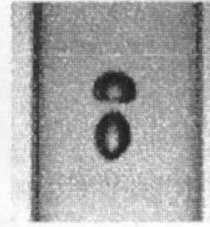

(b)

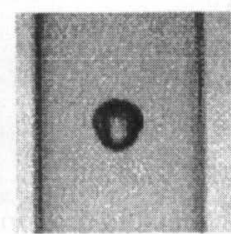

(d)

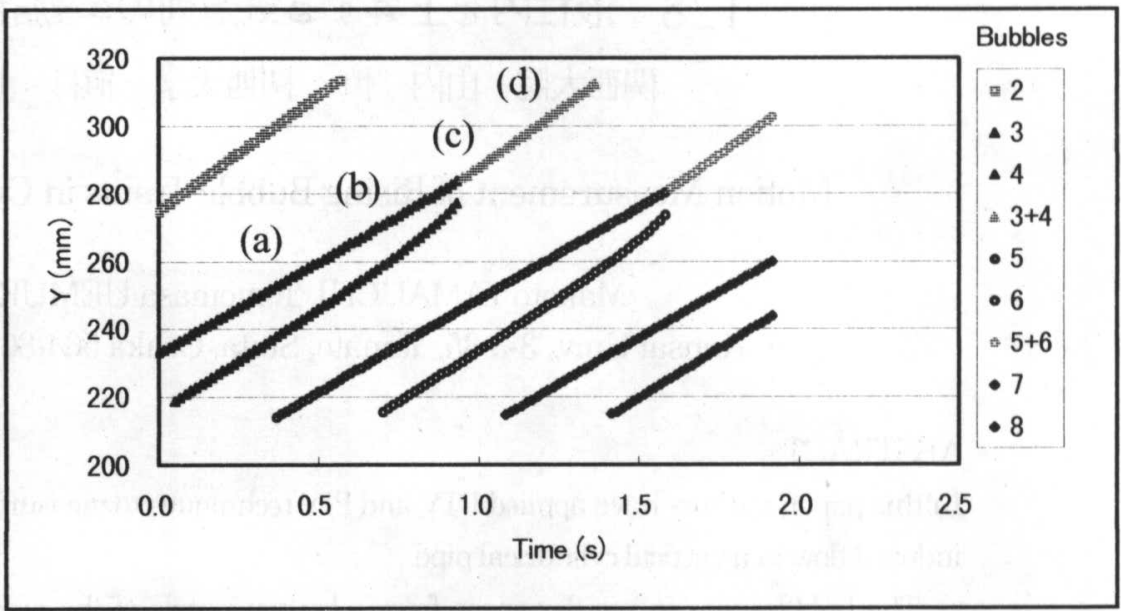

Fig.2 Pictures of coalescing bubbles and measured vertical positions

\section{2. 画像解析の方法}

気泡の上昇速度計測には PTVを用いた。 気泡の抽出では, 気泡の境界周辺の輝度分 布を最小 2 乗法によって 3 次曲線に近似 $L$, 得られた 3 次曲線の変曲点を境界とし ている.この方法を用いて気泡の直径をサ ブピクセル精度で求めている．また，気泡 の表面積および体積は正面,側面両方向か ら撮影した画像を用いて, 気泡を楕円体と 仮定して求めている. また，円管断面内の 気泡の重心位置を時系列的に並心゙て, 気泡 の上昇経路を求めている. 一方，気泡の上 昇に伴う管内の非定常流れの速度分布 の計測にPIV を用いた.これら両者の方 法を用いれば，上昇気泡の速度計測結果 が正しく得られているか知ることがで きる.ここで，単位換算は円管の直径を 基準にして行った.

\section{3. 計測結果及び検討}

\section{1.PTVによる計測結果}

Fig.2 はそれぞれの気泡の先端位置と 時間との関係を示す。ここで, Y 座標は ノズルからの距離である. また,そのとき の原画像の例を左に示す.ここに示すよ うに，後から上昇する気泡(Bubble4)が, 前の気泡(Bubble3)の後流によって上昇速 度が速くなり, やがて前の気泡に追いつい て衝突している様子がわかる.この場合, 衝突点はノズルから約 $280 \mathrm{~mm}$ の位置で, 前の 気泡と後の気泡の上昇速度はそれぞれ $54.2 \mathrm{~mm} / \mathrm{s}, 65.9 \mathrm{~mm} / \mathrm{s}$ であった. したがって, 後の気泡は前の気泡より $20 \%$ 程度上昇速度が

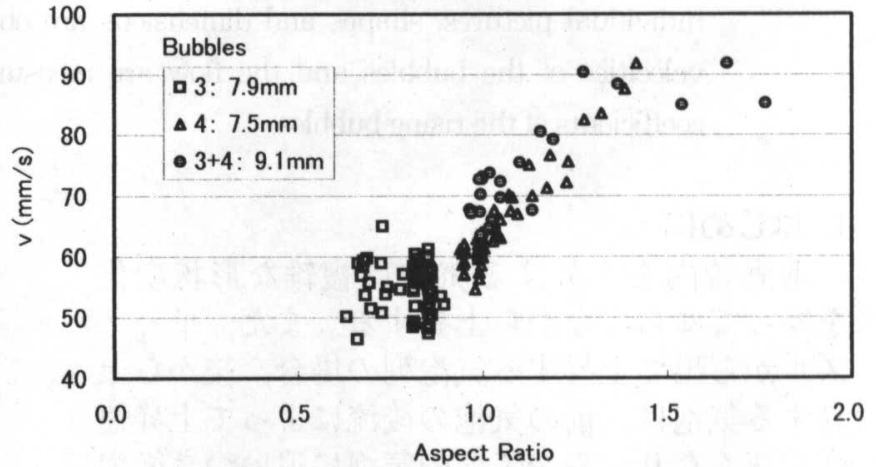

Fig.3 Relationship between rising velocity and aspect ratio of bubbles

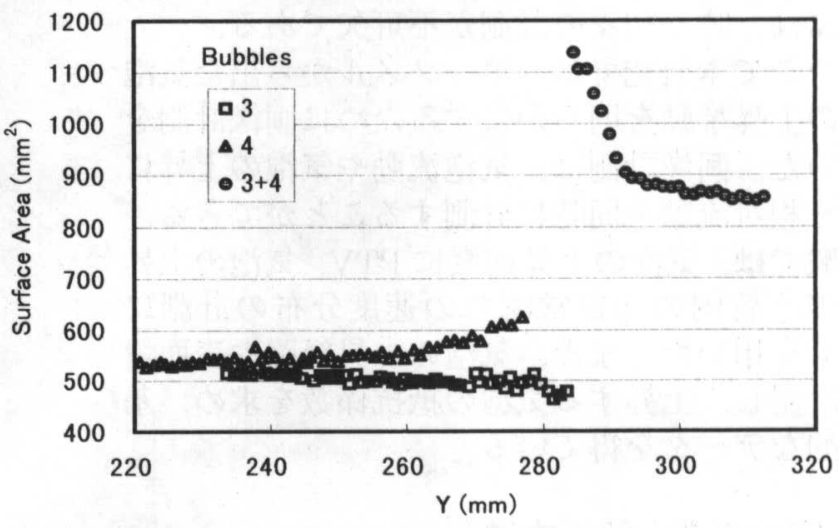

Fig.4 Variation of surface area before and after coalescence of rising bubbles

速い。また，合体後の気泡(Bubble3+4)の上昇 速度は $66.8 \mathrm{~mm} / \mathrm{s}$ で速度変化は見られない。

Fig.3 は気泡の上昇速度とアスペクト比の関 係を示す.ここで, アスペクト比は 1 より大きい 
ものが綐長の気泡を示す.すなわち上昇速度の 遅い前の気泡は, 横長の気泡で,後の気泡と合体 後の気泡はいずれも縦長の気泡を示している.

Fig.4 は気泡の表面積と先端位置の関係を示 す.ここで,表面積及び体積は,気泡を楕円体と仮 定して求めている.

ここに示すように,後から上昇する気泡の方 が前の気泡よりも表面積が大きいことがわかる. 体積については，後の気泡は前の気泡より $2 \%$ 程度大きい.これは,前の気泡の後流によって後 の気泡がノズルから出易いことを示している.

Fig.5 は管断面内の気泡位置の計測例を示し ており, 気泡の重心位置 $\left(\mathrm{x}_{\mathrm{b}}, \mathrm{z}_{\mathrm{b}}\right)$ は円管の半径 $\mathrm{R}$ で無次元化している. 円管断面内の気泡は管の 中心から偏って上昇した.この偏位の原因は実 験装置によるものか, 上昇気泡に伴う現象かは 今のところ検討していない.

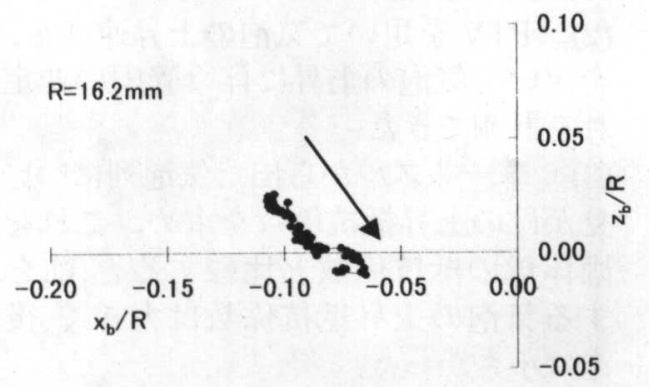

Fig.5 Deviations of bubbles in a horizontal cross section

\section{2. 気泡の抵抗係数}

気泡の上昇速度，直径が計測できたので，見 かけのレイノルズ数, フルード数及び気泡の上 昇抵抗係数を計算することができる. 気泡を球 と仮定した場合, 一般に球の抵抗係数 $\mathrm{C}_{\mathrm{D}}$ は次 式で求めることができる.

$$
\mathrm{D}=\mathrm{C}_{\mathrm{D}} \cdot \mathrm{S} \cdot\left(\rho \mathrm{v}^{2} / 2\right) \quad \cdots(1)
$$

ここで, $\mathrm{D}$ : 抗力 (浮力), $\mathrm{S}$ : 気泡の面積, $\mathrm{r}$ : 気泡の半径である.

得られた結果を Table1 に示す.この結果か ら,後から上昇する気泡の見かけの上昇抵抗係 数は前の気泡の $63 \%$ 程度である.また, 文献 ${ }^{(4)}$ によれば, 粘性流体中での静止固体球の抵抗係 数 $\mathrm{C}_{\mathrm{D}}$ は約 30 である. したがって, 前の気泡 は静止固体球の抵抗係数より大きい結果が得ら れている.これは,前の気泡が上昇する際,上昇 方向の流体を押しのけて,管壁面近傍に下降流
を形成するためと考えられる.一方,後の気泡と 合体後の気泡は,いずれも静止固体球の抵抗倸 数より小さい值を示している.これは, 後の気泡 が前の気泡の後流によって上昇し易いことを示 している.

Table1 Reynolds, Froude and drag coefficient of rising bubbles

\begin{tabular}{|c|c|c|c|}
\hline Bubble & $\mathrm{Re}=\mathrm{vd} / v$ & $\mathrm{Fr}=\mathrm{v} /(\mathrm{Lg})^{0.5}$ & $\mathrm{C}_{\mathrm{D}}$ \\
\hline 3 & 0.86 & 0.20 & 38.9 \\
\hline 4 & 0.99 & 0.25 & 24.7 \\
\hline $3+4$ & 1.47 & 0.27 & 27.1 \\
\hline
\end{tabular}

3. 3. PIVによる計測結果

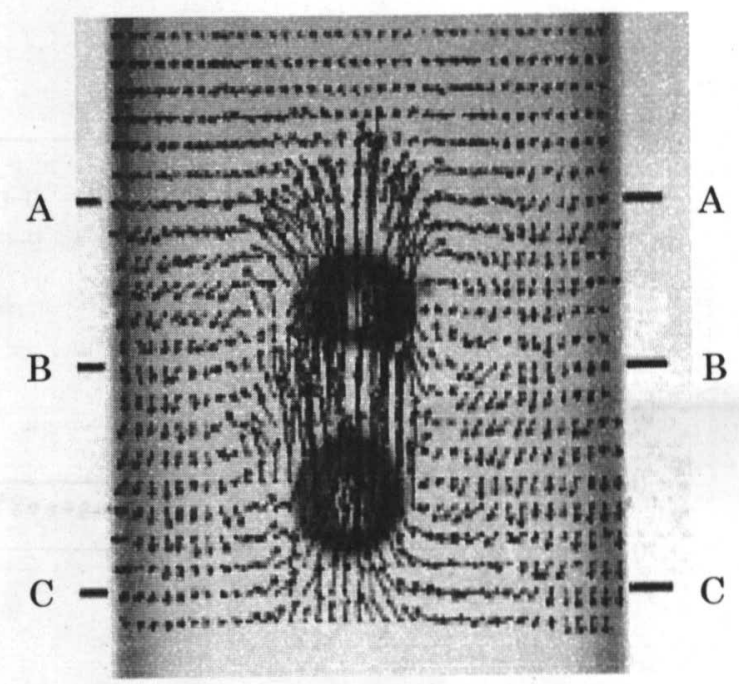

(a)

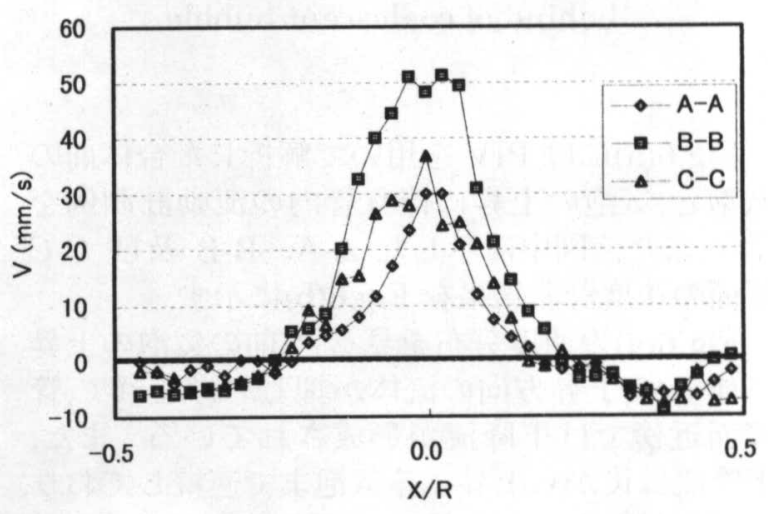

(b)

Fig. 6 Velocity distributions induced by two rising and approaching bubbles 


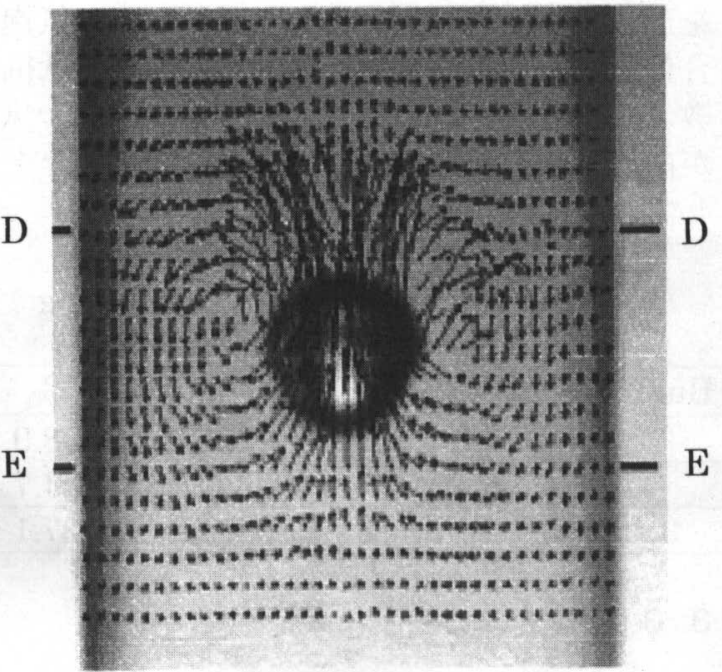

(a)

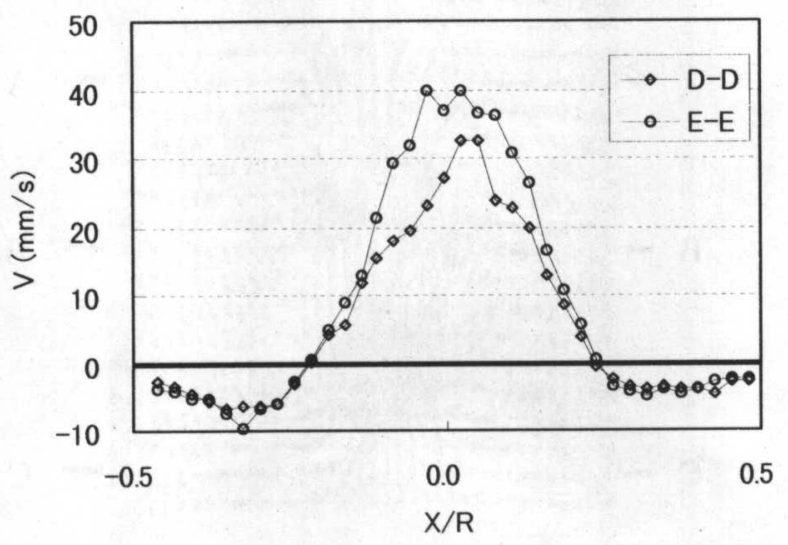

(b)

Fig.7 Velocity distributions in front and behind of coalescent bubble

Fig.6(a)には PIV を用いて解析した合体前の 気泡と,気泡の上昇に伴う管内の流動計測例を 示す.また, 図中に示した A-A, B-B 及び C-C 断面の速度計測結果を Fig.6(b)に示す.

Fig.6(a)の速度分布を見ると,前の気泡の上昇 に伴って,上昇方向の流体が押しのけられて,管 壁面近傍では下降流が形成されている。 また, 下降流は後から上昇する気泡まで連続しており， 2 個 1 対となって上昇している様子を示してい る.また, Fig.6(b)の各断面の速度計測結果から, 下降流の形成されている領域やその速度はほぼ 等しいことを示している.ここで，気泡の重心 位置付近の上昇速度は, 前の気泡が $52.9 \mathrm{~mm} / \mathrm{s}$, 後の気泡が $66.4 \mathrm{~mm} / \mathrm{s}$ であった.

Fig.7(a)には Fig.6(a)の 2 気泡が衝突し,合体
した後の気泡についての速度計測例を示す。

Fig.7(a)の速度分布を見ると, 気泡の近傍の 流れは, 左右対称の渦を形成している.また，下 降流は,気泡周りのみで，合体後は,単体で上昇 していることを示している.

Fig.7(b) より,下降流を形成している領域は, 気泡径の 2 倍程度外側から管壁面近傍までであ ることを示している.ここで, 気泡の重心位置 付近の上昇速度は $62.1 \mathrm{~mm} / \mathrm{s}$ であった。

以上のことから,後から上昇する気泡は前の 気泡の後流によって上昇抵抗が小さく, 上昇速 度が速くなり, やがて前の気泡に追いつき衝突 する過程を定量的に計測することができた.

\section{4. 結論}

以上の研究より得られた結果を要約すると次 の通りである.

（1）上昇する気泡の寸法, 表面積を時系列 で計測できた.

(2) PTV を用いて気泡の上昇速度を, PIV を用いて気泡の上昇に伴う管内の非定常流 れを計測できた。

(3) 単一ノズルから出た気泡列について, 見かけの上昇抵抗係数を求め, これを静止 固体球の抵抗係数と比較すると, 前を上昇 する気泡の上昇抵抗係数は大きく,後の気 泡は小さかった.

\section{5. 参考文献}

1) 吉本, 植村 : 動画像解析のための高速 PTVソフトウェアの開発, 可視化情報長岡 講演会講演論文集 Vol.16 Suppl. No.2(1996), pp.31-34.

2) 利安, 植村 : 逐次棄却法の精度向上に 関する検討 II (解析時間の短縮)，可視化情 報沖縄講演会講演論文集 Vol.17 Suppl. No.2(1997), pp.95-98.

3) 山内, 植村 : 液柱内を上昇する気泡列 の挙動計測, 第 15 回流体計測 - 第 12 回流 体制御合同シンポジウム講演論文集(1997), pp.93-96.

4) S. F. Hoerner, FLUID-DYNAMIC DRAG, Published by the Author(1958), pp.3.7-3.9.

5) 植村, 井口, 他 3 名: 水一空気系底吹 き気泡噴流により攪找される円筒容器内流 れの画像計測, 鉄と鋼第 78 年(1992)第 5 号, pp.738-744.

本研究の遂行に本学大学院生富松重行氏の協力が あったことを記し感謝の意を表します。 